2020, Volume 14, International Conference Innovative Business Management \& Global Entrepreneurship (IBMAGE 2020), pages: 97-107 |

https://doi.org/10.18662/lumproc/ibmage2020/08

\section{Communication, a Premise for Increasing the Organization's Performance}

\section{Constantin Ciprian IACOB', Silvia Elena IACOB ${ }^{2}$}

${ }^{1}$ University Valahia of Targoviste, Romania, av iacobconstantinciprian@yahoo.com

${ }^{2}$ University of Economic Studies, Bucharest, Romania, popescusilviaelena@yahoo.com
Abstract: Communication has always been one of the most important tools through which people can interact with each other. Given that the way we interact with people has never been easy, it has evolved today with more languages, channels and different ways of communicating than before. Communication has a unique role, allowing the solution of certain operational, functional and relational problems, but also employee satisfaction. Recent changes have had an impact on organizations and have increased the importance of managing both internal and external communication. Thus, the communication system is also a system of actions, because the activity and the word are intertwined in negotiations, arguments, counseling, explanation of tasks, conflict resolution. Communication in the educational institution is a premise of the performance of instructive-educational processes, a factor that creates an optimal educational climate, a vector for building the reputation and image of the educational organization and a source of motivation for teachers.

Keywords: communication; organization; image; performance; growth.

How to cite: Iacob, C. C., \& Iacob S. E. (2020).

Communication, a Premise for Increasing the Organization's

Performance. In M. W. Staniewski, V. Vasile, \& A. Grigorescu (vol. ed.), Lumen Proceedings: Vol. 14. International Conference Innovative Business Management \& Global Entrepreneurship (IBMAGE 2020) (pp. 97-107). Iasi, Romania: LUMEN Publishing House.

https://doi.org/10.18662/lumproc/ibmage2020/08 


\section{Introduction}

Recent changes have had an impact on organizations and have increased the importance of managing internal and external communication [2].

Thus, the communication system is also a system of actions, because the activity and the word are intertwined in negotiations, arguments, counseling, explanation of tasks, conflict resolution [6].

In school organizations, it is not the final destination that counts, but the stages completed because we can talk about how speeches, written texts, words produce a collective and social reality attributed to school institutions [9].

\section{Problem Statement}

In addition, the theme is motivated by the belief that when communication is effective it gives the educational organization an advantage, namely the recovery of the reputation diminished by mediocre management of reprehensible acts (conflicts between teachers and students, corruption, behavior contrary to professional ethics) which are heavily publicized) [7].

\section{Research Questions/Aims of the research}

Combining educational policies with traditions of specialized Romanian education, the Technological High School wants to ensure the necessary premises for the development of an education system that is modern [8], open and focused on promoting certain values of European democracy [20]. In figure 1.1. the educational principles of the high school are presented (figure 1.1.). 


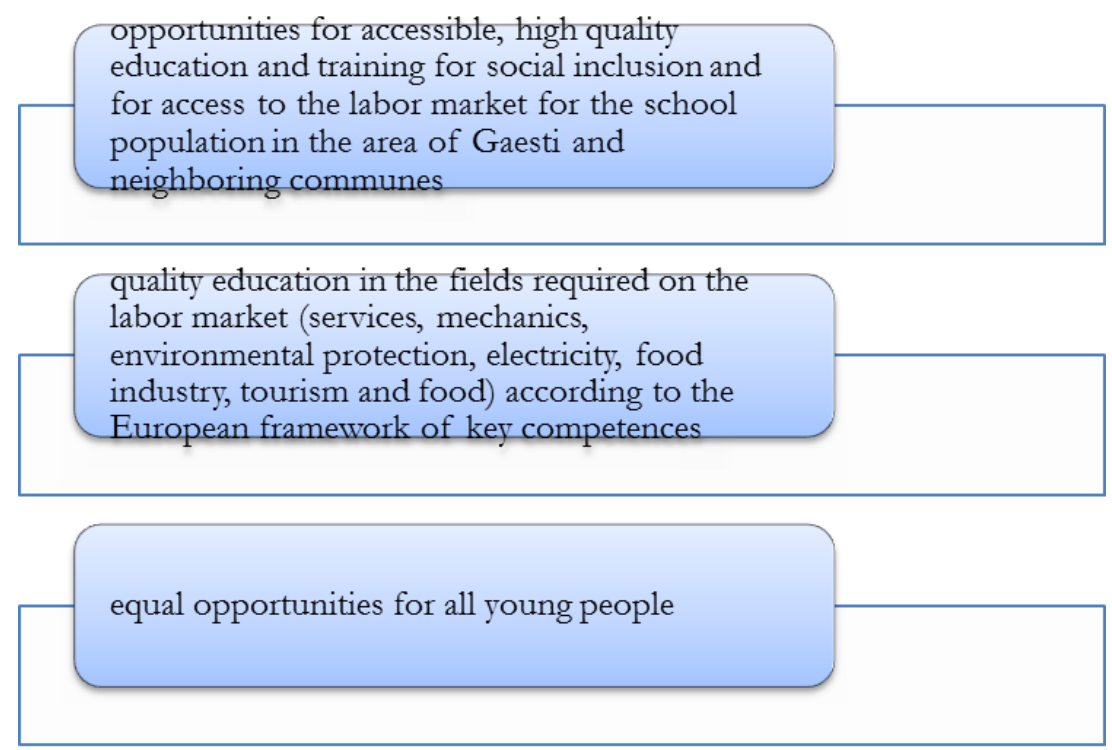

Figure 1.1. The educational principles of the International High School

Source: developed by the author based on high school website information

The main condition for the coherent and correct reception of the message is represented by the approach adopted by the teacher, the procedures, methods, manner but also the modalities used, as well as the environment in which the process takes place [3].

The purpose of the high school is to create certain conditions for the development of talents and interests. Students have the opportunity to participate in various extracurricular activities [22].

Within the high school, the school climate is welcoming and focuses on the individual development of each student [10].

Teachers are considered at the level of the school organization the engine of the institution [11]. The purpose of the research is that communication can be a premise for increasing the performance of the organization [21].

In order to carry out this study at the International High School, we used the questionnaire as a tool [12]. The use of the questionnaire is useful because it can find out the opinions of teachers in an easier way and covers a large sample of individuals, being easy to analyse [19].

\section{Research Methods}

The questionnaire is a psychological and logical sequence of written questions, which are related to the research hypotheses [4]. 
The questionnaire developed for this case study contains 9 questions addressed to a number of 55 teachers, of which 50 answered.

The results of the case study from the Dr. C. Angelescu Technological High School help us to verify whether the following 4 hypotheses will be confirmed or not [15; 23; 24].

- H1: Performance is conditioned by the relationship between teacher and student.

- H2: During the evaluation, the reproduction of the information by the student determines the increase of the teachers 'satisfaction regarding the students' receptivity.

- H3: The development of the prestige of the school organization is based on the optimization of the procedures for regular collection of the feedback of the external partners of the institution (parents, nongovernmental organizations, local authorities).

- H4: Low receptivity of parents in communication relationships with the teacher.

These data were processed using the SPSS (Statistical Package for the Social Sciences) program.

\section{Findings}

Below we present the results of the questionnaire with the help of graphs, where we add the explanations and conclusions that emerge from each graph.

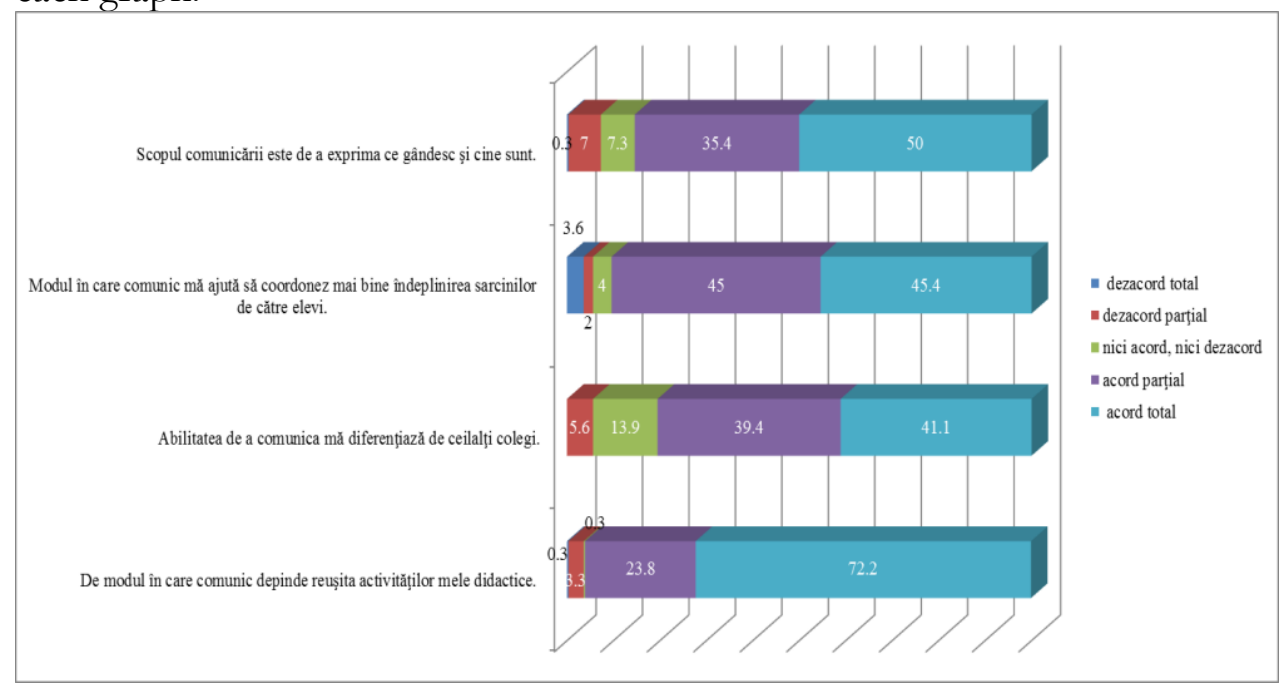

Graph 1.1. Individual representations of teachers about communication

Source: developed by the author 
From the data in graph K1.1 we can see that: $72.2 \%$ of teachers fully agree that the way they communicate determines the success of teaching activities, $50 \%$ believe that the purpose of communication is to express what they are and what they think, $45.4 \%$ fully agree that the way of communication determines a good coordination of the completion of students' tasks and $41.1 \%$ believe that the ability to communicate can differentiate you from other teachers [5].

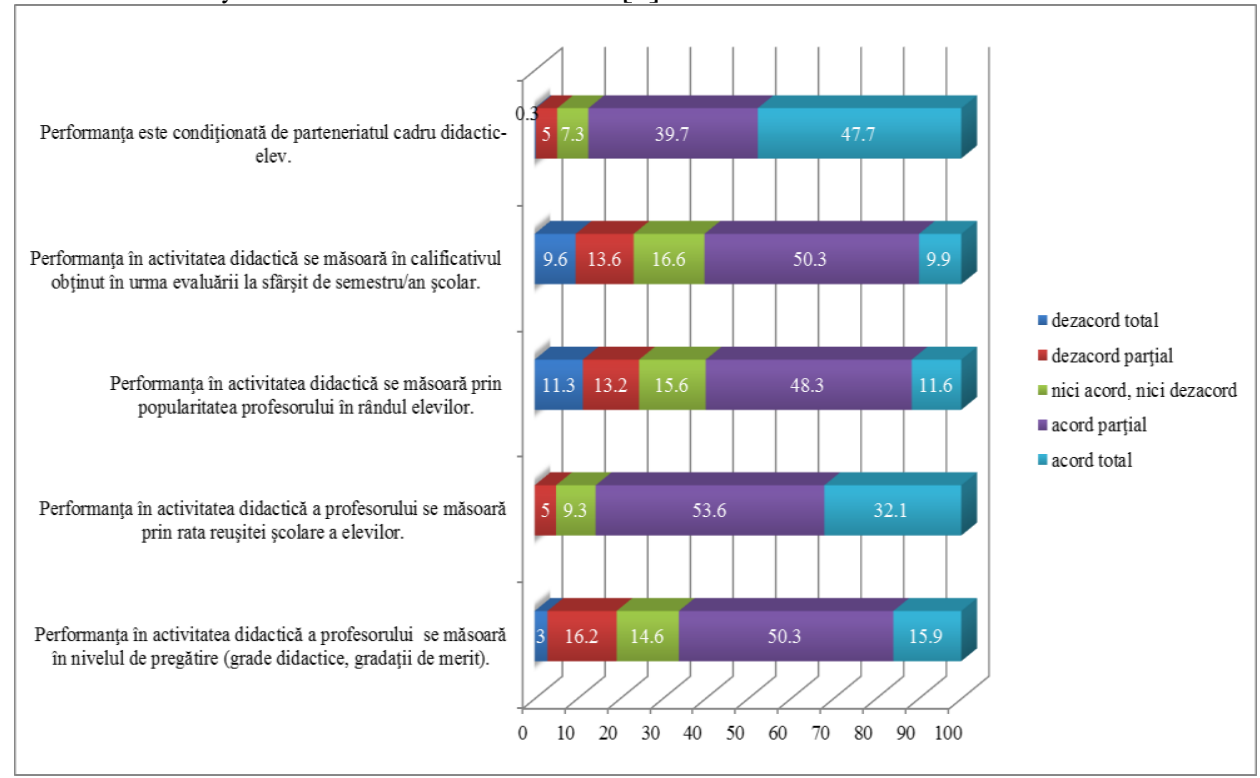

Graph 1.2. Teachers' opinions on performance criteria

Source: developed by the author

As we see in this chart, $47.7 \%$ of teachers fully agree that performance is conditioned by the relationship between teachers and students [14] and partially agree that:

- the performance in the didactic activity is measured with the help of the student's school success rate $(53.6 \%)$;

- performance in teaching activities can be measured following the grade from the end-of-semester assessment (50.3\%);

- teaching performance is measured using the teacher's training level $(50.3 \%)$;

- performance can be measured by the popularity of the teacher $(48.3 \%)$. 


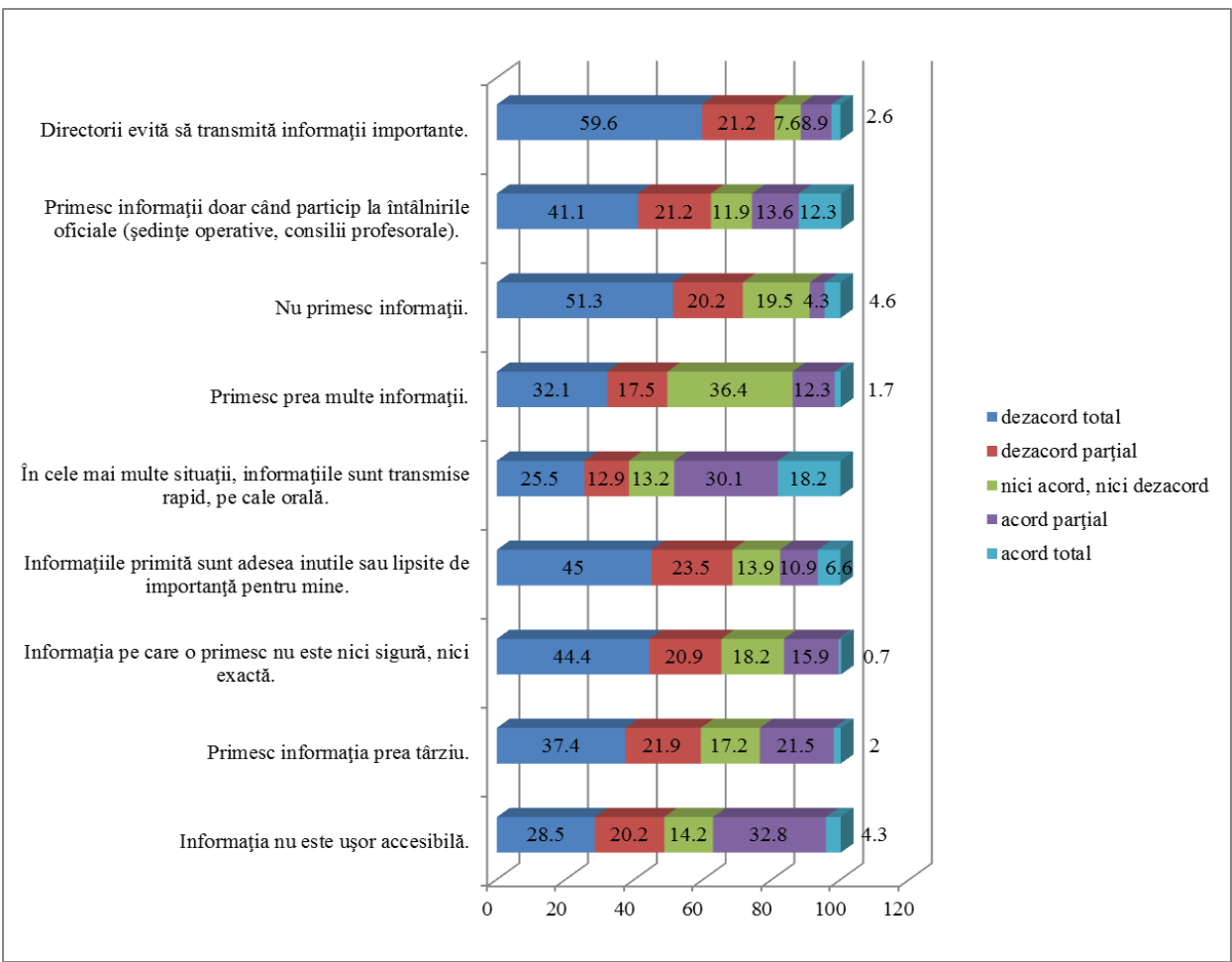

Graph 1.3. Communication deficiencies in the school organization

Source: developed by the author

The graph shows that teachers do not fully agree with the fact that:

- directors avoid transmitting important information (59.6\%);

- do not receive information (51.3\%);

- the information received is in many cases unnecessary or irrelevant $(45 \%)$;

- $\quad$ the information received is not secure and accurate (44.4\%);

- $\quad$ information received is transmitted late $(37.4 \%)$;

- $\quad$ receive various information $(32.1 \%)$;

- $\quad$ information is not easily accessible (28.5\%). 


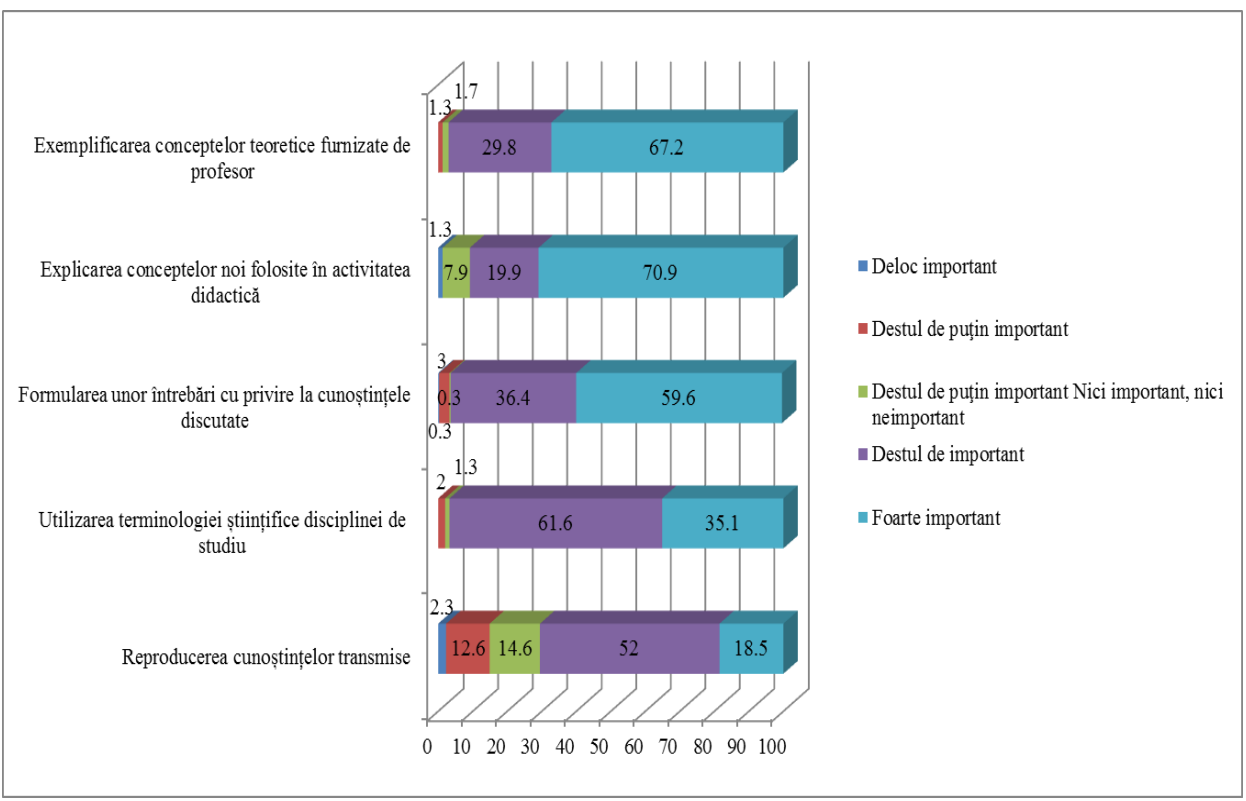

Graph 1.4. The importance of communication in the evaluation process

Source: developed by the author

The graph above shows that respondents consider it very important to:

- $\quad$ explain the new concepts used in the didactic activity $(70.9 \%)$;

- $\quad$ exemplify the theoretical concepts provided $(67.2 \%)$;

- $\quad$ ask questions about the knowledge discussed (59.6\%);

- $\quad$ use the scientific terminology of the study discipline (35.1\%);

- $\quad$ reproduces the transmitted knowledge $(18.5 \%)$.

\section{Discussions}

Communication in the educational institution is a premise of the performance of instructive-educational processes, [22] a factor that creates an optimal educational climate, a vector for building the reputation [18] and image of the educational organization and a source of motivation for teachers [13]. Five hypotheses were verified during the study (table 1.2) 
Table 1.2. Case study hypotheses

\begin{tabular}{|l|l|}
\hline $\begin{array}{l}\text { H1: Performance is conditioned by the } \\
\text { relationship between teacher and student. }\end{array}$ & VERIFIED \\
\hline $\begin{array}{l}\text { H2: During the evaluation, the } \\
\text { reproduction of the information by the student } \\
\text { determines the increase of the teachers } \\
\text { 'satisfaction regarding the students' receptivity. }\end{array}$ & VERIFIED \\
\hline $\begin{array}{l}>\text { H3: The development of the prestige of } \\
\text { the school organization is based on the } \\
\text { optimization of the procedures for regular } \\
\text { collection of the feedback of the external } \\
\text { partners of the institution (parents, non- } \\
\text { governmental organizations, local authorities). }\end{array}$ & VERIFIED \\
\hline $\begin{array}{l}\text { H4: Low receptivity of parents in } \\
\text { communication relationships with the teacher. }\end{array}$ & VERIFIED \\
\hline
\end{tabular}

Source: developed by the author

\section{Conclusions}

In order for the school organization to reach the desired performance [1], it uses both internal and external communication, as well as most of the techniques used in their realization (table 1.3).

Table 1.3. Internal communication and external communication

\begin{tabular}{|l|l|l|}
\hline Analysis criteria & Internal communication & $\begin{array}{l}\text { External } \\
\text { communication }\end{array}$ \\
\hline Scope & Internal environment & External environment \\
\hline $\begin{array}{l}\text { The place of } \\
\text { communication } \\
\text { within the } \\
\text { organization }\end{array}$ & $\begin{array}{l}\text { the communication } \\
\text { related to the identity and } \\
\text { culture of the school } \\
\text { organization is related to } \\
\text { the general policy of the } \\
\text { organization }\end{array}$ & $\begin{array}{l}\text { communication dependent } \\
\text { on the general policy of } \\
\text { the organization and } \\
\text { marketing [16] }\end{array}$ \\
\hline Objectives & $\begin{array}{l}\text { creating a unique and } \\
\text { homogeneous entity } \\
\text { developing solidarity and } \\
\text { cohesion }\end{array}$ & $\begin{array}{l}\text { developing the notoriety } \\
\text { and image of the school } \\
\text { organization } \\
\text { promoting basic } \\
\text { educational services and }\end{array}$ \\
\hline
\end{tabular}




\begin{tabular}{|l|l|l|}
\hline & & $\begin{array}{l}\text { peripheral services } \\
\text { stimulating the } \\
\text { participatory attitude of } \\
\text { the internal educational } \\
\text { actors }\end{array}$ \\
\hline Target audience & $\begin{array}{l}\text { school organization } \\
\text { employees, students, } \\
\text { managers }\end{array}$ & all types of audiences \\
\hline Message & identity message & $\begin{array}{l}\text { commercial message, } \\
\text { identity and message of } \\
\text { legitimacy }\end{array}$ \\
\hline $\begin{array}{l}\text { Duration of the } \\
\text { message }\end{array}$ & $\begin{array}{l}\text { timeless message } \\
\text { regarding his identity part; } \\
\text { medium/long term } \\
\text { message when it emerges } \\
\text { from the general policy of } \\
\text { the school organization }\end{array}$ & $\begin{array}{l}\text { the message is short / } \\
\text { medium term when it is } \\
\text { emerging to marketing and } \\
\text { long term when it results } \\
\text { from the general policy of } \\
\text { the organization [16] }\end{array}$ \\
\hline Techniques used & $\begin{array}{l}\text { integration media } \\
\text { (meetings, meetings, etc.) }\end{array}$ & $\begin{array}{l}\text { dissemination, legitimacy } \\
\text { and integration media }\end{array}$ \\
\hline $\begin{array}{l}\text { Types of } \\
\text { communication }\end{array}$ & $\begin{array}{l}\text { bottom-up } \\
\text { communication (student- } \\
\text { teacher, teacher-director) } \\
\text { top-down communication } \\
\text { (teacher-director, teacher- } \\
\text { student) } \\
\text { lateral communication } \\
\text { (between teachers, } \\
\text { between students) } \\
\text { commercial } \\
\text { communication }\end{array}$ \\
\hline
\end{tabular}

Source: developed by the author

In this context, it is argued that internal communication acts, which are specific to the two dimensions of communication, help the operational effectiveness of the school organization [17]. The documents must be designed to support a process that is necessary to ensure a proper school climate, a friendly learning environment through the adherence, involvement, identification and participation of teachers in the school organization. Thus, through communication, one can stimulate the desire to belong to a group, to interact with others. 


\section{References}

[1] Alcouffe C, Louzzani Y. Mesures de l'investissement immatériel. Indicateurs d'evaluation et de performance. Note du LIRHE. Toulouse. 2003, n³81.

[2] Becker EF, Wortmann J. Mastering Communication at Work: How to Lead, Manage, and Influence. New York: McGraw-Hill, 2009.

[3] Beitone A, Cazorla A, Dollo C, Drai AM. Dictionnaire de science économique.3 Edition Armand Colin. 2010.

[4] Bernard A, Tichkiewitch S. Methods and Tools for Effective Knowledge Life-Cycle- Management. Springer. 2008.

[5] Bertrand M. Gândirea comunicațională. Editura Cartea Românească. Bucureşti. 1998.

[6] Bertrand M. Societatea cucerită de comunicare. Editura Polirom. Iaşi. 2000.

[7] Bouchez J.P. (a), Manager des travailleurs professionnels du savoir : enjeux et perspectives. Revue Française de Gestion. 2006.

[8] Certo, S. Modern management (9th ed.). Boston: Pearson Education International. 2004.

[9] Clampitt, P. G. Communicating for Managerial Effectiveness. Thousand Oaks, Calif: Sage Publications. 2001.

[10] Coman C. Relațiile Publice şi Mass-Media. Editura Polirom. Iaşi. 2004.

[11] Pop D. Introducere în teoria relațiilor publice. Editura Dacia. Cluj-Napoca. 2000.

[12] Newson D. VanSlyke Turk J. dean K. Totul despre Relații Publice. Editura Polirom. Iaşi. 2003.

[13] Edwards G. A cultural approach to evaluating leadership development. Advances in Developing Human Resources. 15 (1), 46-60; 2013.

[14] Kandula SR. Performance Management: Strategies, Interventions, Drivers, PHI Learning 2006.

[15] Kiel F, Lennick D. Moral intelligence - Enhancing business performance and leadership success. Upper Saddle River. New Jersey: Pearson Education 2005.

[16] Lazăr DD. Bazele Marketingului, Vol. I, Editura Casa Cărții de Ştiință, ClujNapoca, 2001.

[17] Lunenburg. Irby. The principalship: vision to action. Belmont, CA: Thomson/Wadsworth. 2006. 
[18] Lungu IC. Politici şi tratamente contabile privind evaluarea performanței financiare a întreprinderii: teză de doctorat. Bucureşti. ASE 2006.

[19] Marr B. Strategic Performance Management. Leveraging and measuring your intangible value drivers. Butterworth-Heinemann. ISBN 0750663922, 2006.

[20] Miller K. Organizational Communication: Approaches and Processes. Wadrsworth : Cengage Learning, 2012.

[21] Mullins L. Management and organisational behaviour (9th ed.). Harlow: Financial Times Prentice Hall, 2010.

[22] Quirke B. Making the Connections Using Internal Communication to Turn Strategy into Action. Aldershot, England: Ashgate, 2008. Google Books. Web. 6 Nov. 2014.

[23] Senge PM. The Fifth Discipline: The Art \& Practice of the Learning Organization. New York: Random House Business, 2006.

[24] Shead M. (2007); Leadership trait theory. Retrieved March 20, 2015, from http://www.leadership501.com/leadership-trait-theory/22/ 